IZA DP No. 8460

Immigrants' 'Ability' and Welfare as a Function of Cultural Diversity: Effect of Cultural Capital at Individual and Local Level

Annie Tubadji

Masood Gheasi

Peter Nijkamp

September 2014 


\title{
Immigrants' 'Ability' and Welfare as a Function of Cultural Diversity: Effect of Cultural Capital at Individual and Local Level
}

\author{
Annie Tubadji \\ University of Regensburg
}

Masood Gheasi

VU University Amsterdam and IZA

Peter Nijkamp

VU University Amsterdam and IZA

Discussion Paper No. 8460

September 2014

\author{
IZA \\ P.O. Box 7240 \\ 53072 Bonn \\ Germany \\ Phone: +49-228-3894-0 \\ Fax: +49-228-3894-180 \\ E-mail: iza@iza.org
}

\begin{abstract}
Any opinions expressed here are those of the author(s) and not those of IZA. Research published in this series may include views on policy, but the institute itself takes no institutional policy positions. The IZA research network is committed to the IZA Guiding Principles of Research Integrity.

The Institute for the Study of Labor (IZA) in Bonn is a local and virtual international research center and a place of communication between science, politics and business. IZA is an independent nonprofit organization supported by Deutsche Post Foundation. The center is associated with the University of Bonn and offers a stimulating research environment through its international network, workshops and conferences, data service, project support, research visits and doctoral program. IZA engages in (i) original and internationally competitive research in all fields of labor economics, (ii) development of policy concepts, and (iii) dissemination of research results and concepts to the interested public.
\end{abstract}

IZA Discussion Papers often represent preliminary work and are circulated to encourage discussion. Citation of such a paper should account for its provisional character. A revised version may be available directly from the author. 


\section{ABSTRACT \\ Immigrants' 'Ability' and Welfare as a Function of Cultural Diversity: Effect of Cultural Capital at Individual and Local Level}

This paper presents an operationalization of a mixed Bourdieu-Mincer-type model that seeks to find evidence for individual and local cultural capital effects on human capital 'ability'. We aim to compare these effects for native workers and immigrants (as well as between immigrants themselves) in a locality. The main objective of the paper is twofold: 1) to examine how ethnic background affects immigrants' schooling results; and 2) to explore the link between the wage differential of immigrant young workers entering the labour market in the context of a locally varying cultural milieu. Our study utilises the 2007-2009 data set for higher professional education (termed HBO in Dutch) graduates from Maastricht University. We use a two-stage least squares (2SLS) estimation method to analyse empirically a system of two equations. In the first Bourdieu-type equation, individual cultural capital, together with school type/quality, explains the individual's schooling achievement. Next, this 'schooling achievement' is employed as an explanatory variable in the second Mincer-type equation, which examines wage differential effects. Our Mincer-type equation is next augmented with a control for the local cultural milieu. We find evidence of ethnic segregation with regard to the quality of educational institution to which immigrants have access, which naturally explains part of the wage differential effect. Moreover, we find that local cultural capital determines the size of the wage gap.

JEL Classification: $\quad$ Z10, O31, O43, R11

Keywords: immigration, wage differential, cultural capital, local cultural milieu, Mincer equation

Corresponding author:

Masood Gheasi

VU University Amsterdam

Department of Spatial Economics

De Boelelaan 1105

1081 HV Amsterdam

The Netherlands

E-mail:m.gheasi@vu.nl 


\section{Introduction}

The cultural-ethnic differences that characterise diasporas have long been debated in the modern economics and migration literature in relation to human capital productivity and wages. Little has been said however, for the influence of the cultural differences on the school to work transition disparities between groups of different cultural background and even less so about the differences in their success at localities with differences in the local cultural milieu. Instead of the standard school to work equilibrium search model, we suggest to look on this question through a specific Bourdieu-Mincer type of model where skill, ability and starting wage differences are explained among other standard factors with the individual cultural status (i.e. cultural capital in Bourdiue sense) and local cultural milieu (in Weberian-Floridian extension for the wage differentials Mincer model).

The issue of what is behind the main drivers of human productivity has stood before labour economics since its genesis. Up to now, the main answer to this query has been developed from a human capital perspective, starting with the Mincer $(1958,1974)$ model formalized by Porath 1967) and penetrating the works of Becker (1964) and Griliches (1973). This stream of theoretical and empirical modelling has managed to open up the discourse on the importance of the three main factors widely perceived to be outstanding with regard to today's human productivity: experience gained over time (which is the basis of Mincer's model); schooling (as Becker's main claim is); and the 'ability' of the worker, which is endogenously formed, but crucial for human productivity and further development (Griliches 1977; Rosen 1972) $^{1}$.

In spite of apparent theoretical mismatches, these important streams of literature agree on a general perception that education shapes the productivity of workers and productivity is viewed as reflected in workers' wage.

Recent research (Capello et al. 2011; Tubadji and Nijkamp 2012) has outlined two main groups of human capital in a locality: (i) incumbently generated (workers who were educated in this locality); and (ii) inflowing human capital (workers that have immigrated into a locality).

\footnotetext{
${ }^{1}$ For a recent summary of details, see Moen and Roehling (2005).
} 
According to the framework of culture-based development (CBD), the 'formation' mechanism of these two groups is usually culturally driven. Regarding the first group of human capital, following a Weberian reasoning, CBD explains the formation of the incumbent population's skills and knowledge as a function of both investments in education and culturally-specific human preferences towards certain types of skills. Secondly, following Weber's idea that localities with different value systems (quantifiable among others by their religious belonging as Protestant vs Catholic) and Florida's (2002a, 2002b, 2005) claim that different cultural milieu in a locality attract different quality of immigrant workers, CBD explains the inflow of immigrants through the cultural gravity hypothesis, wherein immigrants are attracted to localities based on both the type of local cultural milieu (defined as the dominant local value system) and the size of the individual cultural distance (for more details, see Tubadji and Nijkamp 2013). This means an individual effect and a local group effect from cultural on workers' formation through schooling and their future productivity.

The aforementioned human capital groups are also characterized by different cultural backgrounds. A large body of literature indicates differences in productivity and wages between locals and immigrants from one side, and differences in overall productivity as a result of the different degree of heterogeneity within the local workforce from the other side.

The cultural-ethnic differences that characterise the diaspora have long been debated by modern economic and migration-related research. Yet, the focus has always been on the effect of cultural diversity on local development. And the related empirical evidence has remained controversial on whether the effect of cultural diversity is positive or negative. For example, Boeri and Brücker (2005) and Ottaviano and Peri $(2005,2012)$ both find that immigrants have a positive impact, whereas others find that a diverse diaspora is less prosperous, perhaps due to ethnic differences and cultural frictions (see e.g Borjas 1996, 1997, 1999, 2003; Collier 2001; Angrist and Kugler 2003).

At the same time, what is available as a theoretical framework linking cultural diversity and human capital 'ability', is a concept that originated from a sociological perspective and which was vigorously developed in the economics of education literature: the concept of cultural capital, as developed by Pierre Bourdieu (1986). This concept delves deeply into the effects 
that the parental cultural background has on schooling success at the individual level, as well as the formation of an individual's social and economic wellbeing. Widely applied and widely contested, Bourdieu's concept explains the social reproduction of class and occupation in the 1960s France as a culturally driven 'self-fulfilled' prophecy. Elsewhere, the CBD concept has lifted the Bourdieu approach to the aggregate local level, and applied Bourdieu's cultural capital approach to the measurement of the local cultural milieu and an estimation of how this affects local productivity (see Tubadji 2012, 2013). Yet, to our knowledge, Bourdieu's premise of a cultural mechanism influencing social reproduction has never been applied to explain both schooling and wage differentials, and particularly not with regard to migrants.

In the current paper, we aim to use the CBD concept to unite three notions: (i) human capital's reward for productivity (approximated through wage level); (ii) diversity (measured based on groups of human capital with different individual cultural capital-i.e. parental background-locals and immigrants); and (iii) local cultural capital (i.e. local cultural milieu). In doing so, we hope to express the endogeneity of 'ability' and success in terms of schooling and wage differentials. Following the CBD approach, this means to explain schooling differentials with the parental bias on ability, and next to incorporate a cultural mechanism of impact on human capital 'quality' by plugging in local cultural capital measures (like predominant religious backgrounds in a locality) into a Mincer-type model for wage differentials. Put differently, the Bourdieu-Mincer (B-M) model is a system of two equations forming a recursive type of model. The first equation of this model reflects the endogenous culturally biased formation of 'ability'. The second equation recognizes the endogeneity of both the 'quantity' of experience and the quality of schooling (in terms of 'type of school'), both being fairly standard variables in human capital research. Additionally, the effect of local cultural capital is explored in the second equation thus avoiding any local institutional bias in the B-M model. To sum up, our study aims to explore the effect of cultural background and local cultural milieu on individual 'ability', as well as on the efficiency of utilizing this endogenously shaped 'ability' in different local cultural contexts.

Our case study for exploring the suggested Bourdieu-Mincer (B-M) type of model is the full population of graduates from different educational institutions in three different years in the Netherlands. To our knowledge there has never been an attempt to combine these two concepts in order to analyse the diaspora in this country. For the Netherlands, the positive 
effects of immigrants are being felt (for an interesting overview of the literature, see Zorlu and Hartog 2001), yet the immigrants' inferior socio-economic status has been detected in the form of wage differentials (Ghaesi et al. 2013). The reason for this situation of inequality remains unclear. From the perspective of the preceding concepts of cultural capital at the individual and local level and our B-M model reasoning, we can make the following assumptions. Firstly, immigrants' 'ability' is influenced by individual levels of the Bourdieuian drawback effect due to the cultural distance. Secondly, the openness of the local milieu can be expected to exercise positive gravity effects on the local productivity of immigrants.

We find that in the Netherlands culture seems to set the initial conditions through the classical Bourdieu social reproduction effect, but given these initial conditions are equal, still the young workers path is differently developing depending on the local aggregate cultural characteristics of the locality where he/she starts to work after higher education.

The structure of the paper is as follows. Section 2 briefly discusses the literature on cultural capital and the empirical studies of its effects in the Netherlands. It traces the reasoning suggested by CBD with regard to analysing endogenous 'ability' and wage differentials through a B-M-type model, culminating in the formulation of our two main working hypotheses. Section 3 lays down the empirical operationalization of the CBD B-M model, offering a glimpse at the peculiarities of our data set and the planned estimation strategy. Section 4 presents the results and analyses the multiple insights they provide. Section 5 concludes.

\section{Motivations}

The cultural capital hypothesis was first documented by Bourdieu (1973) and Bourdieu and Passeron (1977). It was provided as a paradigm explaining how the educational system in France in the 1960s was culminating in a mechanism for social reproduction of the class structure (for an extensive critical review on the reproduction effect of Bourdieu's concept, see Tzanakis 2011). Individual cultural capital is an inevitable characteristic of every person and is a complex composite of three types of 'assets': transmittable cultural goods (objectified cultural capital); degrees and credentials (institutionalized cultural capital); and attitudes, preferences and behaviour as forms of embodied cultural capital (Bourdieu 1973,1986). The composite characteristic of every individual is strongly path-dependent on her/his parental cultural capital, and is said to strongly influence the socio-economic welfare 
of the individual when all other prerequisites for social and economic prosperity are held equal (Bourdieu 1986, 1973; Bourdieu and Passeron 1977).

After this, the concept was applied in multiple variations, which often led to quite contradictory results. Cultural capital has been one of the most widely tested and debated concepts in educational economics since the 1960s, and has been applied to numerous cases worldwide. Regarding the Netherlands as a case-study in particular, De Graaf (1986) modelled educational attainment as a function of social background and parents' financial and cultural resources. He measured the parents' cultural resources using two variables: 1) reading (e.g. number of hours per week spent reading); and 2) cultural participation (consumption of cultural entertainment). Factor analysis supported the view that these are two different factors. After controlling for financial resources, De Graaf also found different modes of impact on schooling achievement from the two cultural factors: namely, parents' cultural participation/consumption has no impact on children's educational attainment, but parents' reading behaviour has some effect. Moreover, by considering two different cohorts of students (younger cohort $n=317$ families; older cohort $n=221$ families), the author found that the influence of financial resources has disappeared since 1950, while the influence of cultural resources has somewhat declined; meanwhile, parental occupation and education (which is part of their institutionalized cultural capital) both maintain their significance. One of the studies into cultural capital in the Netherlands that has become one of the most prominent and widely cited contributions to the topic is by De Graaf et al. (2000).

These authors deepened the understanding of Bourdieuian tendencies in Dutch society (which were identified by De Graaf in his 1986 study) by analysing a segmented view of the reading habits and fine arts consumption. The authors used a random sample of adults $(n=1,653)$ from the 1992-1993 Netherlands Family Survey. Regression analysis confirmed that after controlling for parental educational attainment, a father's occupational status, parental financial resources, family structure and birth cohort, the effect of parental reading on the respondents' educational attainment was significant, albeit smaller than the effect of financial resources. Parental participation in fine arts had no significant effect. A more recent study by Kraaykamp and van Eijck (2010) added a final confirmation to this line of thought by acknowledging the importance of cultural capital in the Netherlands. 
The Netherlands is a country of intensive immigration flows from different parts of the world during different periods (see Zorlu and Hartog, 2001). The socio-economic achievement and status of these immigrants and their children (i.e. second-generation immigrants) are substantially different from those of the local population (e.g. Heijke, 1979; Bovenkerk et al. 1995). Due to parental background, these immigrants clearly have different individual cultural capital than the locals. Moreover, immigrants' different cultural capital has a different effect on their migration choice (Tubadji and Nijkamp 2012). Furthermore, there is a local cultural capital effect demonstrated by the effect of the different social networks in a locality on differences in the flows of immigrants from the same cultural origin, as in the instance of differences in the immigration flow of Brazilians to the Netherlands compared to those to Portugal (van Meeteren and Pereira 2013). Yet, at least to our knowledge, there is no study that has previously attempted to explain the different social and economic achievements of immigrants in the Netherlands through a Bourdieuian study of the cultural capital of immigrants in comparison to the cultural capital of the local population.

A major criticism on the relevance of cultural capital is that it is strongly related to the idea of social class. However, this argument is a matter of interpretation. While it may be claimed that class systems have been abolished as a social phenomenon, what is constantly reported by abundant international research ${ }^{2}$ and Dutch-specific research ${ }^{3}$ is the inequality in the socio-economic status of immigrants in comparison to the locals. On average, immigrants throughout the European Union are reported to have lower salaries than local workers, even when they share the same educational level. This may or may not be associated with class identification, yet what remains obvious is the association of culturally different groups with observed different socio-economic welfare, often in spite of the same levels of human capital (skills) that they possess. This phenomenon closely resembles the basic setting behind the cultural capital hypothesis.

Additionally, evidence shows that labour market opportunities differ between immigrant workers with identical human capital, even within the same country (for example, see Haas

\footnotetext{
2 See e.g. Chiswick and Miller 1985; Beggs and Chapman 1988; Granato and Kalter 2001; Butcher and DiNardo 2002; Miller and Neo 2003; Demoussis and Giannakopoulos 2007; Manacorda et al. 2012.

${ }^{3}$ See e.g. Hartog and Vriend 1989; van Meeteren and Pereira 2013
} 
and Damelang 2007). Thus, besides the individual cultural effect that can be assumed to hinder individual performance (i.e. endogenously developed 'ability'), there seems to be a locality-specific characteristic that determines how important individual cultural capital will be as a factor for observable wage differences among otherwise equally skilled workers. This phenomenon can be translated at an aggregate level of the same cultural capital hypothesis, since we may observe different socio-economic welfare recently for equally economically important entities. Therefore, we can assume there is a local equivalent of cultural capital (Tubadji 2012, 2013; Tubadji and Nijkamp 2012) that explains why some localities take advantage of the available human capital more efficiently than others. On the other hand, this is also in line with the thinking of Jacobs (1961), Weber (1930), Myrdal (1957) and Tubadji (2012, 2013), who each understood local culture as a source for local economic disparities, and particularly the 'emoting with their feet' of self-selecting migrants, who select the milieu of the locality they move to (e.g . Florida's series of publication 2002a, 2002b, 2005). Based on the above, two research hypotheses are now formulated:

H01: Individual cultural capital determines the differences in access to skill accumulation in a diaspora (Bourdieuian individual cultural capital effect).

H02: Local cultural capital determines the wage differentials between identically skilled workers across localities (CBD local cultural capital effect).

To test the two hypotheses, we first need to define what cultural capital means at the individual and aggregate (local) level in order to guarantee an adequate operationalization of the B-M model. Our measurement approach and the operationalization of our culturallyaugmented (Bourdieu-style) Mincer-type model for analysing wage differentials are respectively discussed in detail in the database sub-section and the estimation strategy subsection of Section 3.

\section{Operationalizing the CBD B-M Model}

\subsection{Database}

To address our two hypotheses empirically, we use data from the Research Centre for Education and Labour Market (ROA) of Maastricht University. These are graduates with the 
same higher education level, i.e. there is no selection bias via a vis their current status as starters at the labour market. Yet informally, they carry their history of different cultural background path-dependence and different abilities while at the same higher education institution, and finally end up at different spatial locations, with differences in the local cultural milieu. This dataset therefore, presents a perfect settings for testing our B-M model, setting formal skills as equal and allowing us to look at the ability and wage differentials among native and immigrants. The survey is based on college graduates (or HBO in Dutch terminology) who graduated between 2006/2007 and 2008/2009. Graduates are surveyed approximately 18 months after they have completed their studies. Our data set comprises socio-economic variables at individual level regarding: the wage, immigrant status, age, the set of personal characteristics standardly controlled for in the Mincer regressions - and a variable on predominant religious belonging at the NUTS2 level.

We have selected graduates aged between 19 and 30 at the time of their graduation, who had undergone full-time study, and who had a full-time job after graduation. We focused our attention on this sub-segment of graduates, since it expresses the standard definition of youth. Furthermore, this age category of school-leavers is known from the youthunemployment literature to be the most sensitive to labour market risks. Moreover, it cures the problem of the test for heterogeneity encountered by the full data set. Table 1 below presents descriptive statistics.

$$
\text { +++ Insert Table } 1 \text { about here +++ }
$$

As can be observed from Table 1, the average graduation age is 24 years old, and the ratio of male to female graduates is between 51 and 52 per cent. The share of second-generation migrants is higher in comparison to first-generation immigrants. Furthermore, the share of graduates with a higher status job is between 14 and 16 per cent. Furthermore, the individual cultural capital is quantified by the status of first- or second-generation immigrants in the Netherlands. Two dummy variables for the first- and second-generation categories will be integrated in the regression model to cross-check the wage differential effect for each of the two groups. The omitted group is the 'native' category. 
Following Weber (1930), the existing local cultural capital is approximated through the concentration of representatives of the Protestant religion across the Netherlands. The main assumption behind our local cultural capital variable is that more ascetic and demanding Protestant beliefs might be associated with a more demanding and restrictive cultural milieu for the culturally different immigrants. As we have only NUTS2 level information about the Protestants concentration in a locality and in any case theoretically what matters is just the predominance of Protestant and not the degree of this predominance, so we consider avoiding biases by opting to use a dummy variable equal to 1 when the local concentration of Protestants is above the average concentration of Protestants for the Netherlands.

Another important characteristic of our data set is related to the fact it contains information about the access to different levels of the Dutch education system For a better clarification of the Dutch education system see Figure1. We use the so-called 'Voorbereidend Wetenschappelijk Onderwijs' (VWO) attendance as a measure of the quality of schooling which an individual has had access to. We expect to capture the endogeneity of 'ability' through the involvement of this variable.

+++ Insert Figure 1 about here +++

Table 2 below shows graduation scores and VWO (pre-university education schools ${ }^{4}$ ). It is interesting to note that the ratio of first-generation immigrants attaining a high score at graduation is greater in comparison to second-generation immigrants. This is unlikely to be a self-selection bias in the current dataset as these people have finally been considered homogeneous enough to be accepted in the exact same educational institution.

$$
\text { +++ Insert Table } 2 \text { about here +++ }
$$

\footnotetext{
${ }^{4}$ VWO (pre-university secondary education) is a six-year school education, and is the highest variant in the secondary education system of the Netherlands. Initially we introduced three dummy variables (VWO, HAVO, and MBO) each representing a different length of schooling. The only dummy, which showed significant, is the VWO. Therefore, we united the other categories and created a dummy variable highly quality school.
} 
We also looked at the descriptive statistics regarding the first and second generation of immigrants on the basis of their parental roots. Table 3 below shows the share of each group. As can be observed from Table 3, the share of graduate immigrants with both parents from non-OECD countries is higher in comparison to other groups in the first generation of immigrants; while for the second generation of immigrants, the share of graduates with a Dutch mother is higher. This strengthens our theoretical expectations on the significance of parental background as a significant explanatory variable for immigrants' 'ability'.

$$
\text { +++ Insert Table } 3 \text { about here +++ }
$$

\subsection{Estimation Strategy}

The simultaneous equations approach was previously used in relation to expressing determinants of schooling success and wages, yet only in a partially satisfactory manner; this was because it aimed to minimize statistical errors while failing to express the mechanism behind the endogeneity of 'ability' itself (see Griliches 1977). In this paper, we test the B-M recursive model of two simultaneous equations using the data described in the previous section. The operational form of our Bourdieu-Mincer model can be stated as follows:

$$
\begin{gathered}
\operatorname{lnScore}=\beta_{0}+\beta_{1} C C_{1}+\beta_{2} S Q+\beta_{3} C C_{L 1}+\varepsilon \\
\text { lnWage }=\beta_{0}+\beta_{1} \text { Age }+\beta_{2} A g e^{2}+\beta_{3} \text { Score }+\beta_{4} X+\beta_{5} C C_{L 2}+\varepsilon
\end{gathered}
$$

where InScore is the school grade achieved by the individual; CC_I captures personal characteristics as a first- or second-generation immigrant; CC_L1 is the local concentration of Protestantism in the place of schooling; and CC_L2 presents the local concentration of Protestantism in the place of employment. SQ is the quality of school attended (a dummy variable for VWO schooling as opposed to any other $)^{5}$.

As a first step towards exploring empirically our B-M model, we test the simple specification of the model as spelled out in model (1), whereby equation 1 is a test of $\mathrm{HO1}$, and equation 2

\footnotetext{
${ }^{5}$ In the Mincer equation it is assumed that the logarithm of earnings are a nonlinear function of experience, and according to the model it can be measured as age minus years of schooling minus the school starting age (5 years). In this study we do not have information on total years of education. Therefore, we use the age and age squared as proxies for experience.
} 
is a test of H02. We expect this model to produce the standard behaviour of the Mincer equation, while also capturing the cultural capital effect, as summarized by the variables: in the first equation, the individual cultural capital (immigrant status) and local share of Protestantism in the place of schooling; and, in the second equation, the schooling grade ${ }^{6}$ and local cultural milieu as a share of Protestantism in the place of employment.

In the second step, dummies for the first and second generation of immigrant will be integrated into the first equation of model (1) above. These dummy variables inform us of the magnitude, and the variation of the effect of cultural capital, after the naturalization phase of the immigrants in subsequent generations. In this way, we aim to reflect the dynamics in the status-effect of cultural capital in the diaspora world.

As a third step, we take into account the fact that the B-M-type model actually explains schooling using type of school and immigration status; but even if the test identifies them as explanatory variables for schooling, this does not account for their interrelation. Therefore, we have integrated an interaction term between a dummy variable in equation 1 of model (1): which is 1 for being generally an immigrant and graduated from high school quality (VWO), to fully address our first hypothesis, assuming that a lower schooling achievement is a result of access to schools and not ability. Ultimately, a logit regression (in which schooltype is regressed against the share of immigrants) helps shed some additional light on the nature of the relationship, although in the absence of data on family income. Heterogeneity issues are cured by addressing each graduation year separately, which is doable as we have enough observations for each class, and post-estimation tests for over and under specification are also conducted to cross-check the reliability of our results.

\section{Results}

We employed the above-described data to analyse the effect of local and individual cultural capital on the personal economic welfare of workers in a diaspora world. Table 4 below presents the result of addressing model (1) with 2SLS. The three specifications in Table 4 reflect the results for the years 2007, 2008 and 2009. Table 4 below presents our results.

+++ Insert Table 4 about here +++

\footnotetext{
${ }^{6}$ As an indirect, personally and culturally impacted factor.
} 
According to the available data, our B-M model (1) fully covers the expected behaviour of a Mincer equation - even within the youth age category represented in our data - as the ageand gender-specific variables report significant levels of the expected signs ${ }^{7}$. This effect also has a turning point when, apart from one age in the age-effect variable, it assumes a negative sign. In the Mincer regressions, this effect is usually explained by the experience of the employee. We understand this effect here, however, as a result of the natural balance between age-biased expectations of a graduate's work potential and the objective workexperience category to which all graduates belong together. As expected, a gender gap in favour of male workers is also observed, which is typical of the Central European environment.

It is interesting to observe that the effects of cultural capital on both the individual and local level are registered as strongly significant. This result helps to explain in greater detail the previously obscure reasons for wage differentials in a diverse world. In particluar, in the first equation of model (1), we find that schooling results are strongly dependent on the type of school attended.

Also, the immigrant dummies (first- and second-generation immigrants) are negatively related to a natural logarithm in the graduation score, which is strongly significant for second-generation immigrants. This implies that second-generation immigrants seem to experience a disadvantageous position with regard to schooling grades, especially in a context where school-type seems to impact school grades both significantly and positively. This result can have two complementary explanations. On the one hand, it strongly suggests that second-generation immigrants possibly have access to lower quality schools; on the other hand, though we do not have income data, the results suggest that first-generation immigrants have a human-capital skill advantage. In this situation, if the children of firstgeneration immigrants do not have access to high-quality schools due to their parents' inferior income, then this will mean the parents' income is in itself inferior due to a Bourdieu-type bias, i.e. since their schooling achievement is high, this would suggest a higher income.

\footnotetext{
${ }^{7}$ In other words, as age increases, people in the Netherlands are as assumed to have better work potential by employers, and their wage level grows as a result.
} 
It is highly surprising that first-generation immigrants are more likely to manage better with educational requirements in a foreign language, while second-generation immigrants, who should be empowered by better native language skills, perform worse (see Ofek and Santos 1979). The reason for this is likely that second-generation immigrants are a more heterogeneous entity, free from self-selection bias, who compete on equal terms with the native students but suffer from negative cultural capital aftermaths from their schooling grades due to their parents' cultural distance from the local milieu. This reasoning leads to the conclusion that perhaps it is indeed a Bourdieuian individual cultural capital effect that hinders the development of second-generation immigrants due to institutional cultural capital differences (such as ethnic origin), when the rest of the prerequisites for school grading are held equal between immigrants and locals. Local cultural capital measured by share of Protestants does not register a significant effect in the first schooling grade equation.

The second equation of our model, however, registers a highly significant role of local cultural capital when job search and employment is involved. First, schooling grades are reported as highly significant for wage differentials, meaning that there is already an individual cultural capital effect embedded as a dormant factor in the process'predetermined conditions (in terms of schooling results). Put differently, 'ability' is confirmed to be endogenously shaped through a Bourdieu-type cultural-bias-driven mechanism, which results in differing degrees of access to high quality schooling. Second, the local cultural milieu - measured by share of Protestants in the locality - also exhibits a strongly significant negative effect, thus confirming our expectation of local culture affecting wage differentials in the disapora's labour market. In other words, depending on what the local cultural milieu is like, an immigrant (as well as any other worker) is likely to have a different wage from an equally skilled worker in a locality with differing levels of local cultural capital.

Immigrants are even more affected by this local capital impact on wage differentials across localities, because immigrants are culturally pre-set (through the Bourdieu mechanism) with lower schooling achievements, which supposes lower pay according to the standard human 
capital theory. In other words, immigrants have lower wages than locals due to their own individual cultural capital, and the wage gap between equally talented workers in different localities is higher between immigrants and local workers than between local workers in the same localities due to the local cultural capital effect acting alongside the individual cultural effect that created the gap between locals and immigrants in the first place.

In addition to the above, we included interaction terms between being an immigrant and attending a VWO school; these did not register an impact. We interpret these results as confirmation that the attainment of a high 'ability' is not related to being an immigrant or not being an immigrant, as all students at VWOs attain higher marks; this leads to the conclusion that the problem of immigrants' school attainment is related to their lower concentrations at such schools, and is not due to their inborn talents exhibited once ending up at a good quality school. This confirms a Bourdieuian rationale that it is not one's actual skills but rather the structural treatment from the educational system based on one's cultural background which determines somebody's final schooling attainment. This conclusion needs to be cross-checked in an additional step by directly addressing VWO attainment, previous schooling results and immigrant background. But first we want to study in further detail the meaning of the detected cultural effects on a more filigree classification of parental cultural background. The over- and under-identification test also reports satisfactory levels, therefore we consider our results for reliably informative.

We therefore proceed to examine the impact of parents' roots (i.e. parental bias) on educational attainment. Table 5 below presents the results.

\section{+++ Insert Table 5 about here +++}

The following is what we consider as one of the most interesting results from our B-M model. Table 5 presents the results from augmenting the B-M modelling of immigrants with more information about their parents' roots (i.e. country of origin). The results from the augmented $\mathrm{B}-\mathrm{M}$ model confirm our findings from the simple $\mathrm{B}-\mathrm{M}$ model. In addition, the augmented model demonstrates that second-generation immigrants with parents from nonOECD countries perform worse compared to our reference category (where both parents are Dutch nationals). Put differently, these results demonstrate a high significance of cultural 
distance for the individual success rate of immigrants. Moreover, our results for 2008 indicates that if individuals have a native father or native mother, they also perform worse compared to our reference category. However, if individuals have a Dutch mother, they perform slightly better (0.003 per cent) than when they have a Dutch father. This is probably due to the language effect that a Dutch mother can pass to her child, which is in support of previous research findings (see for example, Ofeka and Santos 1979).

In the third step, we used the logit model to evaluate first- and second-generation immigrants at VWO schools. Table 6 presents the result for our logit model.

\section{+++ Insert Table 6 about here +++}

First of all, the small p-value for the logit regressed chi-squared statistic implies that one or more of the five effects added in the logit model is important for predicting the probability of graduating from a VWO school. The result for the first generation of immigrants is only statistically significant for 2008, which indicates that there is a negative association between first-generation immigrants and our dependent variable (those who graduated from VWO schools). This implies that a one-unit increase in the number of first-generation immigrants decreases the probability of graduating from VWO schools in 2008 by -0.765 . The result for the second generation of immigrants shows a somewhat stable pattern for all three years, and the probability of graduating from VWO schools range between -0.32 and -0.37 .

The logit model confirms our pervious explanation about the disadvantaged position of second-generation immigrants in the Netherlands, despite their language and Dutch culturespecific capabilities. In the Dutch case, one could probably argue that parental cultural endowment is necessary for a successful higher education, but empirical studies have not reached a conclusive decision on whether this affects a child's educational performance (Katsillis and Rubinson 1990; Kingston 2001; van de Werfhorst and Hofstede 2007) while, our own results stand for actually a better performance of the first generation immigrants' category. Therefore, the reason for the current condition of second-generation immigrants is likely to be due to a decreased motivation resulting from experiencing first-hand discrimination at a young age. In short, our findings may provoke interest in a further analysis, with more detailed data on discrimination and access to education, in order to shed 
additional light on the apparent impact that individual and local culture has on the immigrants' human capital formation and utilization in the Netherlands.

Additionally, we applied 2sls to infer the same hypothesis. The result was somehow consistent, but the Hausmann indicted higher efficiency of the 3sls in our case. Therefore we present the 3sls estimations.

\section{Conclusion}

In summary, the results from testing our two hypotheses show that, as expected by standard human capital theory, there is a positive and significant relationship between the quality of schools and graduation scores from higher education institutions. However, immigrants tend to be associated with lower schooling achievements, and second-generation immigrants (which are supposed to be better equipped with language skills) are performing worse in comparison to first-generation immigrants. This means two things: 1) our results confirm the findings of previous studies wherein parental background has a significant impact on the future educational attainments of their children; and 2) immigrants' 'ability' is a function of access to schooling.

On the one hand, there is a clear indication that more caution is warranted for the belief that the conventional variable 'language skills' can be considered a reliable approximation of culture: parental bias stemming from parental cultural capital (in a Bourdieuian sense) seems to be a more significant factor than cultural skills per se. On the other hand, educational returns for the individual (or one's wage) are a function of school quality. This means that second-generation immigrants may have access to lower quality schools, resulting in them ending up with lower skills than first-generation immigrants and locals. Since the explanation might also be found the self-selection of the first generation, we subjected this insight to further analysis. To do so, we differentiated between first- and second-generation immigrants on the basis of their parents' roots. Our results indicated that second-generation immigrants with parents from non-OECD countries are performing worse. This is probably due to the fact that after the Second World War, the Netherlands hosted a large number of guest workers from non-OECD countries; most of these migrants were lowskilled workers. 
Yet, it is also likely that the poor performance of the children of first-generation migrants based on the higher cultural distance between these immigrants and the local cultural milieu. Also, the poor performance of graduates with roots from non-OECD countries may be further explained by the local cultural capital factor (described by the spread of Protestantism in a locality). Our empirical analysis confirms the existence of effects from both individual cultural capital and local cultural capital on 'ability' and wage differentials, thus failing to reject both working hypotheses of our inquiry. In a final step, we crosschecked the identified relationship between immigrant status and access to high quality schools, which seems to be the core link between the individual and local cultural impact on the immigrants' socio-economic success in the Netherlands. The results confirm the relevance of this relationship, and open the way for further exploration of the possible hidden structures discriminating against immigrants.

\section{References}

Algan, Y., Dustmann, C., Glitz, A., and Manning, A. (2010). The economic situation of first and second-generation immigrants in France, Germany and the United Kingdom. The Economic Journal, 120: F4-F30.

Angrist, J. D., and Kugler, D. (2003). Protective or counter-productive? Labour market institutions and the effect of immigration on EU natives. The Economics Journal, 113: 302-331.

Baycan-Levent, T. (2010). Diversity and creativity as seedbeds for urban and regional dynamics. European Planning Studies, 18(4): 565-594.

Becker, S.G. (1964) Human Capital: A Theoretical and Empirical Analysis, with Special Reference to Education. University of Chicago Press: Chicago.

Beggs, J., and Chapman, B. (1988). The forgone earnings from child rearing (Discussion Paper No. 190). Canberra: Centre for Economic Policy Research, Australian National University. 
Behtoui, A. (2004). Unequal opportunities for young people with immigrant backgrounds in the Swedish labour market. Labour, 18: 633-660.

Belzil, C., and Hansen, J. (2003) Structural estimates of the intergenerational education correlation. Journal of Applied Econometrics, 18: 679-696.

Boeri, T., and Brücker, H. (2005). Why are Europeans so tough on migrants? Economic Policy, 20: 629-703.

Borjas, G. J. (2003). The labor demand curve is downward sloping: Reexamining the impact of immigration on the labor market. Quarterly Journal of Economics, 118:1335-1374.

Borjas, G. J. (1999). The economic analysis of immigration. In: O. Ashenfelter and D. Card (eds.) Handbook of Labor Economics (Vol. 3; pp.1697-1760). Elsevier.

Borjas, G. J., and Bernt, B. (1996). Who leaves? The outmigration of the foreign-born. Review of Economics and Statistics, 78:165-176.

Bourdieu, P. (1973). Culture reproduction and social reproduction. In: R. Brown (eds.) Knowledge, Education and Social Change: papers in the Sociology of Education (pp. 71112). Tavisock: London.

Bourdieu, P. (1986). The forms of capital. In: J. G. Richardson (ed.) Handbook of theory and research for the sociology of education (pp.241-258). Greenwood: New York.

Bourdieu, P., and Passeron, J. C (1977). Reproduction in Education Society and Culture. Chicago, IL: University of Chicago Press.

Bovenkerk, F., Gras, M. J. I., and Ramsoedh, D (1995). Discrimination against migrant workers and ethnic minorities in access to employment in the Netherlands. Geneva: International Labour Organization.

Brand, J. E., and Xie, Y. (2010) Who benefits most from college? Eveidence for negative selection in heterogeneous economic returns to higher education. American Sociological Review, 75: 273- 302.

Butcher, K. F., and Dinardo, J. (2002). The immigrant and native born wage distributions: Evidence from United States censuses. Industrial and Labor Relations Review, 56: 97121. 
Capello, R., Caragliu, A., and Nijkamp, P. (2011) Territorial capital and regional growth: increasing returns in knowledge use. Tijdschrift voor Economische en Sociale Geograife, 102: $385-405$.

Card, D. (1999) The Causal Effect of Education on Earnings. In: Orlay, C. Ashenfelter., and D. Card (eds.) Handbook of Labor Economics (Volume 3, Part A. Pp. 1801-1863). Elsevier

Card, D., and Lemieux, T. (2001) Can falling supply explain the rising return to college for younger men?. Quarterly Journal of Economics, 116: 705-746.

Chiswick, B., and Miller, P. W (1985). Immigrant generation and income in Australia. Economic Record, 61: 540-553.

Collier, P. (2001). Implications of ethnic diversity. Economic Policy, 16: 127-166.

De Graaf, P. M. (1986). The impact of financial and cultural resources on educational attainment in the Netherlands. Sociology of Education, 5(9): 237-246.

De Graaf, N. D., De Graaf, P., and Kraaykamp, G. (2000). Parental cultural capital and educational attainment in the Netherlands: A refinement of the cultural capital perspective. Sociology of Education, 73: 92-111.

Demoussis, M., and Giannakopoulos, N. (2007) Exploring job satisfaction in private and public employment: empirical evidence from Greece. Labour, 21: 333-359.

Dronkers, J., and Heus, M. de (2010). Negative selectivity of Europe's guest-workers immigration? The educational achievement of children of immigrants compared with the educational achievement of native children in their origin countries. In: E. de Corte and J. Fenstad (eds.) From Information to Knowledge; from Knowledge to Wisdom: Challenges and Changes facing Higher Education in the Digital Age (pp.89-104). London: Portland Press.

Dronkers, J. Velden, R., and Dunne, A. (2011). The effects of educational systems, schoolcomposition, track-level, parental background and immigrants' origins on the achievement of 15 -years old native and immigrant students. A reanalysis of PIS (Research Memoranda 006). Maastricht: Research Centre for Education and the Labour Market (ROA). 
Florida, R. (2002a). Bohemia and economic geography. Journal of Economic Geography, 2: $55-71$.

Florida, R. (2002b). The Rise of the Creative Class: And How it's Transforming Work, Leisure, Community, and Everyday Life. New York, NY: Basic Books.

Florida, R. (2005). The Flight of the Creative Class: The New Global Competition for Talent. London: Harper Collins.

Gheasi, M., Nijkamp, P., and Rietveld, P. (2013). Wage Gaps between Native and Migrant Graduates of Higher Education Institutions in the Netherlands, unpublished manuscript. Vrije Universitiet van Amsterdam.

Granato, N., and Kalter, F. (2001). Die Persistenz ethnischer Ungleichheit auf dem deutschen Arbeitsmarkt. Diskriminierung oder Unterinvestition? [The Persistence of Ethnic Inequality in the German labour market: Discrimination or under-investment in human capital?]. Kölner Zeitschrift für Soziologie und Sozialpsychologie, 53: 497-520.

Griliches, Z. (1973) Research Expenditures and Growth Accounting. In: B. R. Williams (eds.) Science and Technology in Economic Growth (pp. 59-95). MacMillan: London.

Griliches, Z. (1977) Economic Problems of Measuring Returns to Research. In: Y. Elkana et al. (eds.) Toward a Metric of Science: The Advent of Science Indicators. pp 171-179. John Wiley \& Sons, Inc: New York.

Haas, A., and Damelang, A. (2007). Labour market entry of migrants in Germany: Does cultural diversity matter? (IAB-Discussion Paper, 18/2007). Nürnberg: IAB.

Hanushek, E. A., Woessmann, L. (2008) The role of cognitive skills in economic development. Journal of Economic Literature, 46: 607-668.

Hartog, J., and Vriend, N. (1989). Post-war international labour mobility: The Netherlands. In: A. Thirlwall and I. Gordon (eds.) European factor mobility: Trends and consequences (pp.74-94). London: MacMillan.

Heijke, H. (1979). Sociaal-economische aspecten van gastarbeid. (Doctoral dissertation). Stichting Het Nederlands Economisch Instituut, Rotterdam. 
Herring, C. (2009). Does diversity pay? Race, gender, and the business case for diversity. American Sociological Review, 74(2): 208-224.

Jacobs, J. (1961). The Death and Life of Great American Cities. New York: Vintage.

Katsillis, J., and Rubinson, R. (1990). Cultural capital, student achievement, and educational reproduction: The case of Greece. American Sociological Review, 55: 270-279.

Kingston, P. W. (2001). The unfulfilled promise of cultural capital theory. Sociology of Education, 74: 88-99.

Kraaykamp, G., and van Eijck, K. (2010). The intergenerational reproduction of cultural capital: A threefold perspective. Social Forces, 89(1): 209-231.

Manacorda, M., Manning, A., and Wadsworth, J. (2012) The impact of immigration on the structure of wages: theory and evidence from Britain. Journal of the European Economic Association, 10:120-151.

Miller, P. W., and Neo, L. M. (2003). Labour market flexibility and immigrant adjustment. Economic Record, 79: 336-356.

Milliken, F. J., and Martins L. L. (1996). Searching for common threads: Understanding the multiple effects of diversity in organizational groups. The Academy of Management Review, 21(2): 402-433.

Mincer, J. (1958) Investment in human capital and personal income distribution. The Journal of Political Economy, 66:281-302.

Mincer, J. (1974) Schooling, Experience and Earnings. National Bureau of Economic Research: New York.

Moen, P., and Roehling, P. V. (2005) The Career Mystique: Cracks in the American Dream. The Rowman and Littlefield Publishing Group, Inc: Maryland.

Myrdal, G. (1957). Rich lands and poor, the road to world prosperity. New York, NY: Harper and Row. 
Ofek, H., Santos, F. P. (1979) The economic attainment of women: a comparative analysis of the parental role. Economica, 46:427-433.

Ottaviano, G., and Peri, G. (2005). Cities and cultures. Journal of Urban Economics, 58: 304307.

Ottaviano, G., and Peri, G. (2012). Rethinking the effect of immigration on wages. Journal of European Economics Association, 10:152-197.

Porath, B. Y. (1967) The production of human capital and the life cycle of earnings. The Journal of Political Economy, 75:352-365.

Putnam, R. D. (2007). E pluribus unum: Diversity and community in the twenty-first century. Scandinavian Political Studies, 30(2):137-174.

Rodríguez-Pose, A., and von Berlepsch, V. (2013). European migration, national origin and long-term economic development in the US (Papers in Evolutionary Economic Geography (PEEG) 1305). Utrecht: Utrecht University, Department of Economic Geography. Revised April 2013.

Rosen, S. (1972) Learning and experience in the labor market. Journal of Human Resources, 7: 326-342.

Saiz, A., and Zoido, E. (2005) Listening to what the world says: bilingualism and earnings in the United States. The Review of Economics and Statistics, 87: 523-538.

Tubadji, A., and P. Nijkamp (2013). Culture-based development - A concept of culture as an encompassing economic factor. International Journal of Society Systems Science, forthcoming.

Tubadji, A., and P. Nijkamp (2012). Altruism to strangers for our own sake: Domestic effects from immigration - A comparative analysis for EU15 (Discussion Papers from Tinbergen Institute, 12-079/3). Amsterdam: Tinbergen Institute.

Tzanakis, M. (2011). Bourdieu's social reproduction thesis and the role of cultural capital in education attainment: A critical review of key empirical studies. Educate, 11: 76-90.

van de Werfhorst, H. G., and Hofstede, S. (2007). Cultural capital or relative risk aversion? Two mechanisms for educational inequality compared. The British Journal of Sociology, 58: $391-415$ 
van Meeteren, M., and S. Pereira (2013). The differential role of social networks: Strategies and routes in Brazilian migration to Portugal and the Netherlands (Discussion Paper No. 2013-10). London: Norface Research Programme on Migration, University College London.

Weber, M. (1930). The Protestant ethic and the spirit of capitalism. London \& Boston, MA: Unwin Hyman. First published 1904-1905.

Zorlu, A., and Hartog J. (2001). Migration and immigrants: The case of the Netherlands (Discussion Paper, TI 2001-042/3). Amsterdam: Tinbergen Institute. 
Figure 1: Dutch education system

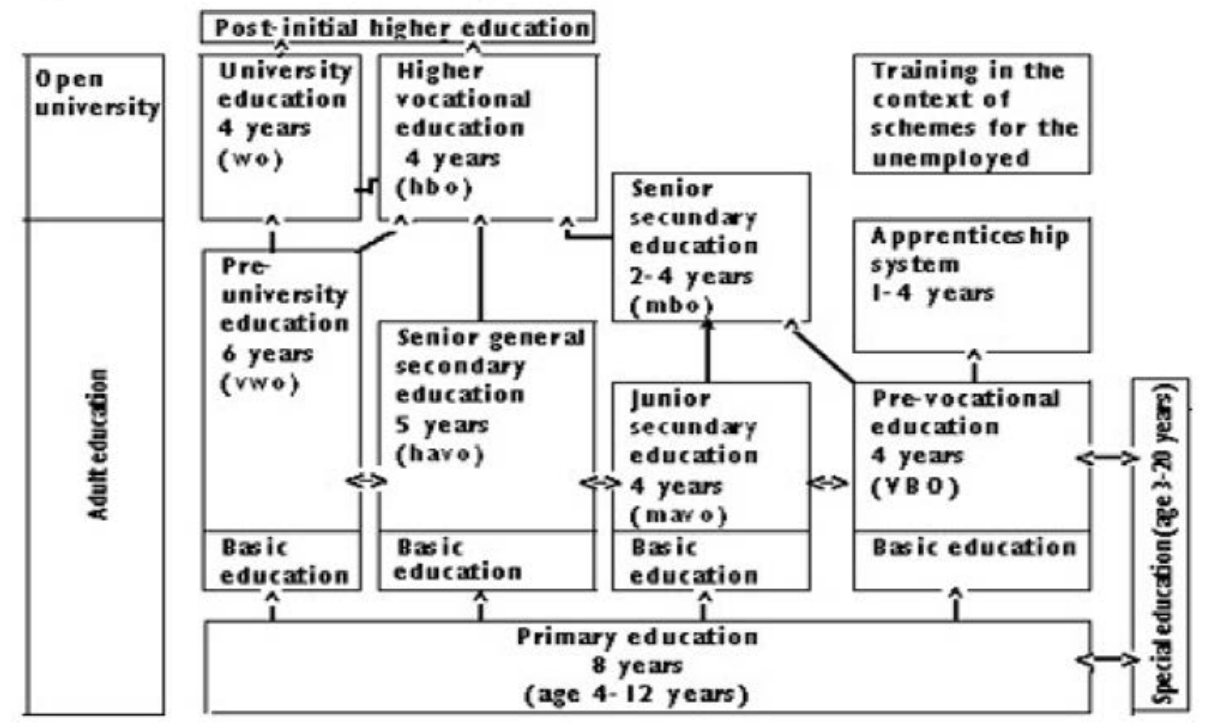

Source: Min. of Sc. and Ed., 1994.

Table 1: Summary Statistics of Main Variables

\begin{tabular}{lccc}
\hline & $\mathbf{2 0 0 7}$ & $\mathbf{2 0 0 8}$ & $\mathbf{2 0 0 9}$ \\
\hline Age & & Mean & \\
Gender (male=1) & 24.648 & 24.443 & 24.434 \\
Native & 0.523 & 0.508 & 0.514 \\
$1^{\text {st }}$ generation of migrants & 0.891 & 0.884 & 0.893 \\
$2^{\text {nd }}$ generation of migrants & 0.026 & 0.028 & 0.030 \\
Supervisor position & 0.083 & 0.088 & 0.077 \\
Jobless $>10$ months before 1st job & 0.156 & 0.144 & 0.154 \\
Observation & 0.014 & 0.016 & 0.010 \\
\hline
\end{tabular}


Table 2: Average graduation score and share of graduates in pre-university education schools

\begin{tabular}{lccc}
\hline & Native & $\begin{array}{c}\mathbf{1}^{\text {st }} \text { generation } \\
\text { migrants }\end{array}$ & $\begin{array}{c}\mathbf{2}^{\text {nd }} \text { generation } \\
\text { migrants }\end{array}$ \\
\hline $\mathbf{2 0 0 7}$ & 0.083 & 0.052 & 0.050 \\
Graduation score 8-10 & 0.182 & 0.181 & 0.156 \\
VWO (pre-university secondary education) & $\mathbf{4 0 4 6}$ & $\mathbf{1 1 6}$ & $\mathbf{3 7 9}$ \\
Number of observations & & & \\
$\mathbf{2 0 0 8}$ & 0.262 & 0.224 & 0.171 \\
Graduation score 8-10 & 0.163 & 0.086 & 0.131 \\
VWO (pre-university secondary education) & $\mathbf{4 9 0 5}$ & $\mathbf{1 5 2}$ & $\mathbf{4 9 0}$ \\
Number of observations & & & \\
2009 & 0.242 & 0.229 & 0.184 \\
Graduation score 8-10 & 0.151 & 0.107 & 0.126 \\
VWO (pre-university secondary education) & $\mathbf{4 2 1 7}$ & $\mathbf{1 4 0}$ & $\mathbf{3 6 5}$ \\
Number of observations & &
\end{tabular}

Table 3: Parent's roots and share of each category at VWO school

\begin{tabular}{lcccccc}
\hline & \multicolumn{2}{c}{$\mathbf{2 0 0 7}$} & \multicolumn{2}{c}{$\mathbf{2 0 0 8}$} & \multicolumn{2}{c}{2009} \\
\hline $\begin{array}{l}\text { The first generation of } \\
\text { migrants }\end{array}$ & $\begin{array}{c}\text { Parent's } \\
\text { root }\end{array}$ & $\begin{array}{c}\text { VWO } \\
\text { school } \\
\text { share }\end{array}$ & $\begin{array}{c}\text { Parent's } \\
\text { root }\end{array}$ & $\begin{array}{c}\text { VWO } \\
\text { school } \\
\text { share }\end{array}$ & $\begin{array}{c}\text { Parent's } \\
\text { root }\end{array}$ & $\begin{array}{c}\text { VWO } \\
\text { school } \\
\text { share }\end{array}$ \\
\hline Mother \& father OECD & 0.104 & 0.142 & 0.118 & 0.231 & 0.121 & 0.333 \\
Mother \& father non-OECD & 0.672 & 0.810 & 0.651 & 0.538 & 0.736 & 0.667 \\
Mother \& father Turk & 0.086 & 0.048 & 0.112 & 0.154 & 0.050 & 0 \\
Mother \& father Moroccan & 0.138 & 0 & 0.119 & 0.077 & 0.093 & 0 \\
Ob Nr. & $\mathbf{1 1 6}$ & $\mathbf{2 1}$ & $\mathbf{1 5 2}$ & $\mathbf{1 3}$ & $\mathbf{1 4 0}$ & $\mathbf{1 5}$ \\
\hline The second generation of & & & & & & \\
migrants & & & & & & \\
\hline Mother \& father OECD & 0.040 & 0 & 0.012 & 0.030 & 0.013 & 0.022 \\
Mother \& father non-OECD & 0.214 & 0.186 & 0.182 & 0.141 & 0.183 & 0.130 \\
Mother \& father Turk & 0.079 & 0.051 & 0.110 & 0.047 & 0.068 & 0 \\
Mother \& father Moroccan & 0.045 & 0.017 & 0.063 & 0.016 & 0.038 & 0.043 \\
Mother Dutch & 0.319 & 0.424 & 0.339 & 0.422 & 0.358 & 0.348 \\
Father Dutch & 0.303 & 0.322 & 0.294 & 0.344 & 0.340 & 0.457 \\
Ob Nr. & $\mathbf{3 7 9}$ & $\mathbf{5 9}$ & $\mathbf{4 9 0}$ & $\mathbf{6 4}$ & $\mathbf{3 9 9}$ & $\mathbf{4 6}$ \\
\hline
\end{tabular}


Table 4: 2SLS simultaneous equations simple B-M model (with 1st and 2 nd generation of immigrants, and natives)

Year 2007

Year 2008

Year 2009

First stage

Ln (graduation score)

\begin{tabular}{|c|c|c|c|c|c|c|}
\hline 1st generation immigrants & 0.026 & 0.026 & -0.0042 & 0.0127 & -0.00311 & -0.0260 \\
\hline & $(0.033)$ & (0.0374) & (0.0316) & (0.0327) & (0.0331) & $(0.0356)$ \\
\hline 2nd generation immigrants & -0.021 & -0.0166 & $-0.0634 * * *$ & $-0.0588 * * *$ & -0.0234 & $-0.0289 *$ \\
\hline & $(0.020)$ & $(0.0216)$ & $(0.0171)$ & $(0.0176)$ & $(0.0161)$ & $(0.0173)$ \\
\hline Male & $-0.085 * * *$ & $-0.085 * * *$ & $-0.0629 * * *$ & $-0.0627 * * *$ & $-0.0399 * * *$ & $-0.0401 * * *$ \\
\hline & $(0.011)$ & $(0.0113)$ & $(0.0099)$ & $(0.0099)$ & $(0.0105)$ & $(0.0104)$ \\
\hline High_Q_school (VWO) & $0.103 * * *$ & $0.105 * * *$ & $0.0756 * * *$ & $0.0814 * * *$ & $0.105^{* * *}$ & $0.0978 * * *$ \\
\hline & $(0.013)$ & $(0.014)$ & $(0.0130)$ & $(0.0134)$ & $(0.0136)$ & $(0.0144)$ \\
\hline 1st generation * VWO & & -0.002 & & $-0.188^{*}$ & & $0.2074 * * *$ \\
\hline & & $(0.0708)$ & & $(0.112)$ & & $(0.0793)$ \\
\hline 2nd generation * VWO & & -0.027 & & -0.0339 & & 0.0449 \\
\hline & & $(0.0516)$ & & (0.0587) & & $(0.0453)$ \\
\hline Protestant (dummy) & $-0.024 * *$ & $-0.025 * *$ & -0.0068 & -0.0066 & $-0.0362 * * *$ & $-0.0359 * * *$ \\
\hline & $(0.011)$ & $(0.011)$ & (0.0098) & $(0.0098)$ & $(0.0103)$ & $(0.0103)$ \\
\hline Constant & $2.356 * * *$ & $2.365^{* * *}$ & $3.464 * * *$ & $3.518 * * *$ & $3.069 * * *$ & $3.032 * * *$ \\
\hline & $(0.811)$ & $(0.811)$ & 0.848 & $(0.848)$ & $(0.840)$ & $(0.8401)$ \\
\hline Observations & 4341 & 4341 & 5381 & 5381 & 4559 & 4559 \\
\hline
\end{tabular}

Robust standard errors in parentheses ${ }^{* * *} p<0.01,{ }^{* *} p<0.05,{ }^{*} p<0.1$

\begin{tabular}{|c|c|c|c|c|c|c|}
\hline \multirow[b]{2}{*}{ Second stage } & \multicolumn{2}{|c|}{ Year 2007} & \multicolumn{2}{|c|}{ Year 2008} & \multicolumn{2}{|c|}{ Year 2009} \\
\hline & & & n(gross mo & nthly salary & & \\
\hline Male & $\begin{array}{l}0.088 * * * \\
(0.0073)\end{array}$ & $\begin{array}{c}0.0883^{* * *} \\
(0.0073)\end{array}$ & $\begin{array}{c}0.0927^{* * *} \\
(0.0062)\end{array}$ & $\begin{array}{c}0.0941 * * * \\
(0.00613)\end{array}$ & $\begin{array}{c}0.0758 * * * \\
(0.0057)\end{array}$ & $\begin{array}{l}0.0744 * * * \\
(0.00552)\end{array}$ \\
\hline Age & $\begin{array}{c}0.0199 \\
(0.0304)\end{array}$ & $\begin{array}{c}0.0200 \\
(0.0304)\end{array}$ & $\begin{array}{c}0.113 * * * \\
(0.0325)\end{array}$ & $\begin{array}{c}0.116 * * * \\
(0.0326)\end{array}$ & $\begin{array}{c}0.125 * * * \\
(0.0352)\end{array}$ & $\begin{array}{l}0.121 * * * \\
(0.0350)\end{array}$ \\
\hline Age (sq) & $\begin{array}{l}-6.56 \mathrm{e}^{-05} \\
(0.0006)\end{array}$ & $\begin{array}{l}-6.72 e^{-05} \\
(0.0006)\end{array}$ & $\begin{array}{c}- \\
0.0019 * * * \\
(0.00064)\end{array}$ & $\begin{array}{c}- \\
0.00197 * * * \\
(0.000646)\end{array}$ & $\begin{array}{c}-0.0022^{* * *} \\
(0.0007)\end{array}$ & $\begin{array}{l}0.00213 * * * \\
(0.000699)\end{array}$ \\
\hline Ln_score & $\begin{array}{l}0.126 * * \\
(0.0584)\end{array}$ & $\begin{array}{l}0.130 * * \\
(0.0583)\end{array}$ & $\begin{array}{c}0.0924 \\
(0.0658)\end{array}$ & $\begin{array}{c}0.114^{*} \\
(0.0635)\end{array}$ & $\begin{array}{c}0.120 * \\
(0.0652)\end{array}$ & $\begin{array}{c}0.0864 \\
(0.0596)\end{array}$ \\
\hline Protestant (a dummy) & $\begin{array}{c}-0.0233 * * * \\
(0.0052)\end{array}$ & $\begin{array}{l}-0.0232 * * * \\
(0.00518)\end{array}$ & $\begin{array}{c}-0.0375 * * * \\
(0.0044)\end{array}$ & $\begin{array}{c}-0.0374 * * * \\
(0.00439)\end{array}$ & $\begin{array}{c}-0.0377^{* * *} \\
(0.00535)\end{array}$ & $\begin{array}{l}-0.0388 * * * \\
(0.000524)\end{array}$ \\
\hline $\begin{array}{l}\text { Jobless > } 10 \text { months } \\
\text { before } 1 \text { st job }\end{array}$ & $\begin{array}{c}-0.0812 * * * \\
(0.0227)\end{array}$ & $\begin{array}{c}-0.0809 * * * \\
(0.0227)\end{array}$ & $\begin{array}{c}-0.067^{* * *} \\
(0.0171)\end{array}$ & $\begin{array}{l}-0.0658 * * * \\
(0.0172)\end{array}$ & $\begin{array}{l}-0.126 * * * \\
(0.0296)\end{array}$ & $\begin{array}{c}-0.126 * * * \\
(0.0287)\end{array}$ \\
\hline Supervisor position & $\begin{array}{c}0.0316 * * * \\
(0.0074)\end{array}$ & $\begin{array}{l}0.0316 * * * \\
(0.0074)\end{array}$ & $\begin{array}{c}0.0222 * * * \\
(0.0066)\end{array}$ & $\begin{array}{l}0.0219 * * * \\
(0.00669)\end{array}$ & $\begin{array}{c}0.00669 \\
(0.00747)\end{array}$ & $\begin{array}{l}0.00714 \\
(0.0074)\end{array}$ \\
\hline Constant & $\begin{array}{c}7.119 * * * \\
(0.366)\end{array}$ & $\begin{array}{r}7.007^{* * *} \\
(0.400)\end{array}$ & $\begin{array}{l}5.928 * * * \\
(0.4421)\end{array}$ & $\begin{array}{l}5.860 * * * \\
(0.441)\end{array}$ & $\begin{array}{c}5.799 * * * \\
(0.468)\end{array}$ & $\begin{array}{c}5.892 * * * \\
(0.461)\end{array}$ \\
\hline $\begin{array}{l}\text { Sargan statistic test } \\
\text { Chi-sq(2) P-val }\end{array}$ & $\begin{array}{c}3.142 \\
(0.2078)\end{array}$ & $\begin{array}{r}5.109 \\
(0.2763)\end{array}$ & $\begin{array}{c}2.839 \\
(0.2418)\end{array}$ & $\begin{array}{c}4.332 \\
(0.3629)\end{array}$ & $\begin{array}{c}4.515 \\
(0.1046)\end{array}$ & $\begin{array}{c}9.614 \\
(0.0475)\end{array}$ \\
\hline
\end{tabular}

Robust standard errors are in parentheses ${ }^{* * *} p<0.01,{ }^{* *} p<0.05,{ }^{*} p<0.1$ 
Table 5: 2SLS simultaneous equation model for B-M model with detailed parent-based analysis

\begin{tabular}{|c|c|c|c|}
\hline \multirow[b]{2}{*}{ First stage } & Year 2007 & Year 2008 & Year 2009 \\
\hline & \multicolumn{3}{|c|}{ Ln (graduation score) } \\
\hline \multirow[t]{2}{*}{ Mother \& father Moroccan (1st) } & -0.00405 & -0.0268 & -0.0011 \\
\hline & $(0.0772)$ & $(0.0474)$ & $(0.0642)$ \\
\hline \multirow[t]{2}{*}{ Mother \& father Turks (1st) } & -0.0702 & 0.0308 & 0.0402 \\
\hline & $(0.187)$ & $(0.0737)$ & $(0.129)$ \\
\hline \multirow[t]{2}{*}{ Mother \& father non- OECD (1st) } & 0.0196 & -0.00114 & -0.0288 \\
\hline & $(0.0379)$ & $(0.0421)$ & $(0.0412)$ \\
\hline \multirow[t]{2}{*}{ Mother \& father OECD (1st) } & $0.180 * * *$ & -0.0338 & $0.135 * *$ \\
\hline & $(0.0415)$ & $(0.0947)$ & $(0.0635)$ \\
\hline \multirow[t]{2}{*}{ Mother \& father Moroccan (2nd) } & -0.114 & -0.029 & 0.00226 \\
\hline & $(0.108)$ & $(0.0500)$ & $(0.0494)$ \\
\hline \multirow[t]{2}{*}{ Mother \& father Turks (2nd) } & -0.0919 & -0.0384 & -0.0601 \\
\hline & $(0.0726)$ & $(0.0429)$ & $(0.0580)$ \\
\hline \multirow[t]{2}{*}{ Mother \& father non-OECD (2nd) } & -0.0667 & $-0.141 * * *$ & $-0.0739 *$ \\
\hline & $(0.0428)$ & $(0.0472)$ & $(0.0383)$ \\
\hline \multirow[t]{2}{*}{ Mother \& father OECD (2nd) } & 0.0841 & -0.0694 & $-0.160 * * *$ \\
\hline & $(0.0714)$ & $(0.135)$ & $(0.0204)$ \\
\hline \multirow[t]{2}{*}{ Dutch mother (2nd) } & 0.0253 & $-0.0484 *$ & 0.0190 \\
\hline & (0.0298) & $(0.0252)$ & $(0.0247)$ \\
\hline \multirow[t]{2}{*}{ Dutch father (2nd) } & -0.0216 & $-0.0548^{*}$ & -0.0325 \\
\hline & (0.0326) & $(0.0307)$ & $(0.0261)$ \\
\hline \multirow[t]{2}{*}{ Male } & $-0.0847 * * *$ & $-0.0636 * * *$ & $-0.0409 * * *$ \\
\hline & (0.0113) & (0.00995) & $(0.0105)$ \\
\hline \multirow[t]{2}{*}{ Protestant (a dummy) } & $-0.0250 * *$ & -0.00788 & $-0.0373 * * *$ \\
\hline & $(0.0110)$ & $(0.00979)$ & $(0.0103)$ \\
\hline \multirow[t]{2}{*}{ High_Q_school (VWO) } & $0.102 * * *$ & $0.0754 * * *$ & $0.105 * * *$ \\
\hline & $(0.0143)$ & $(0.0131)$ & $(0.0136)$ \\
\hline \multirow[t]{4}{*}{ Constant } & $2.303 * * *$ & $3.478 * * *$ & $3.086 * * *$ \\
\hline & $(0.812)$ & $(0.851)$ & $(0.840)$ \\
\hline & & & Year 2009 \\
\hline & Year 2007 & Year 2008 & \\
\hline Second stage & \multicolumn{3}{|c|}{ Ln(gross monthly salary) } \\
\hline \multirow[t]{2}{*}{ Male } & $0.0823 * * *$ & $0.0916 * * *$ & $0.0757 * * *$ \\
\hline & $(0.0069)$ & $(0.00631)$ & $(0.0055)$ \\
\hline \multirow[t]{2}{*}{ Age } & 0.0172 & $0.111 * * *$ & $0.125 * * *$ \\
\hline & $(0.0297)$ & (0.0324) & $(0.0351)$ \\
\hline \multirow[t]{2}{*}{ Age (sq) } & 0.000039 & $-0.00188 * * *$ & $-0.0022 * * *$ \\
\hline & $(0.000588)$ & $(0.00064)$ & $(0.0007)$ \\
\hline Supervisor position & $0.0322 * * *$ & $0.0223 * * *$ & 0.00669 \\
\hline & (0.0073) & $(0.00663)$ & $(0.00747)$ \\
\hline Ln_score & 0.0648 & 0.0751 & $0.118 * *$ \\
\hline & (0.0523) & $(0.0676)$ & $(0.0607)$ \\
\hline Jobless $>10$ months before $1^{\text {st }}$ job & $-0.0867 * * *$ & $-0.0687^{* * *}$ & $-0.126 * * *$ \\
\hline & $(0.022)$ & (0.0169) & $(0.0295)$ \\
\hline Protestant (a dummy) & $-0.0250 * * *$ & $-0.0376 * * *$ & $-0.0377^{* * *}$ \\
\hline & $(0.00502)$ & $(0.00435)$ & $(0.00529)$ \\
\hline Constant & $7.14^{* * *}$ & $5.984 * * *$ & $5.801 * * *$ \\
\hline & $(0.387)$ & $(0.443)$ & $(0.463)$ \\
\hline Sargan statistic test & 19.919 & 13.275 & 7.868 \\
\hline Chi-sq(2) P-val & $(0.012)$ & $(0.1027)$ & $(0.4465)$ \\
\hline Observations & 4,341 & 5,381 & 4,559 \\
\hline
\end{tabular}

Robust standard errors are in parentheses $* * * p<0.01, * * p<0.05, * p<0.1$ 
Table 6: Logit regression of high quality school (VWO)

\begin{tabular}{lccc}
\hline & Year 2007 & Year 2008 & Year 2009 \\
& & High quality school (VWO) & -0.401 \\
\hline $1^{\text {st }}$ generation immigrants & -0.0793 & $-0.765^{* * *}$ & $(0.278)$ \\
& $(0.252)$ & $(0.293)$ & $-0.321^{* *}$ \\
$2^{\text {nd }}$ generation immigrants & $-0.289^{*}$ & $-0.285^{* *}$ & $(0.163)$ \\
& $(0.152)$ & $(0.140)$ & $-0.213^{* * *}$ \\
Male & $-0.374^{* * *}$ & $-0.177^{* *}$ & $(0.0824)$ \\
& $(0.0785)$ & $(0.0738)$ & 0.0403 \\
Protestant (dummy) & $-0.246^{* * *}$ & -0.121 & $(0.0834)$ \\
& $(0.0791)$ & $(0.0743)$ & $-1.634^{* * *}$ \\
Constant & $-1.179^{* * *}$ & $-1.477^{* * *}$ & $(0.0746)$ \\
& $(0.0674)$ & $(0.0663)$ & 12.99 \\
LR chi2 (4) & 35.23 & 19.52 & 0.0113 \\
Prob> chi2 & 0.000 & 0.001 & 0.0033 \\
Pseudo R2 & 0.0084 & 0.004 & 4,710 \\
Observations & 4435 & 5545 & 5 \\
Goodness to fit & & & 1.02 \\
Number of groups & 6 & 4 & 0.796 \\
Hosmer-Lemeshow chi ${ }^{2}(3)$ & 0.69 & 0.0769 & 5.13 \\
Prob $>$ chi2 & 0.9524 & & \\
\hline Standard errors are in parentheses & $* * * p<0.01 * * *<0.05 * *<0.1$ & \\
\end{tabular}

